Crop Breeding and Applied Biotechnology 13: 144-151, 2013

Brazilian Society of Plant Breeding. Printed in Brazil

\title{
ARTICLE
}

\section{Adaptability and stability of sweet sorghum cultivars}

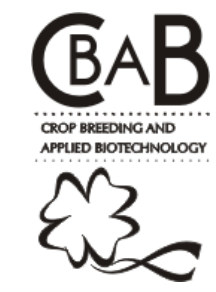

Vander Fillipe de Souza ${ }^{*}$, Rafael Augusto da Costa Parrella ${ }^{2}$, Flávio Dessaune Tardin², Márcia Regina Costa ${ }^{3}$, Geraldo Afonso de Carvalho Júnior ${ }^{4}$ and Robert Eugene Schaffert ${ }^{2}$

Received 15 February 2012

Accepted 18 October 2012

\begin{abstract}
The objective of this study was to evaluate the phenotypic stability and adaptability of 25 sweet sorghum cultivars of Embrapa Maize and Sorghum. The experiments were conducted in five Brazilian environments, three in the state of Minas Gerais, and the others in Sinop, Mato Grosso and Pelotas, Rio Grande do Sul. Fresh biomass yield (FBY), and total soluble solids (TSS) of the juice were evaluated in a randomized complete block design with three replications. Analysis of variance showed significant genotype by environment interaction for both traits. According to the Annicchiarico methodology analysis, genotypes CMSXS634, BRS506, and CMSXS646 were the most stable and adapted for FBY and TSS concomitantly; CMSXS634 being more adapted to favorable environments and CMSXS646 being more adapted to unfavorable environments.
\end{abstract}

Key words: Sorghum bicolor, genotype x environment interaction, Annicchiarico, biofuel, ethanol.

\section{INTRODUCTION}

Among the main energy crops, sweet sorghum stands out as a very promising feed stock, resulting in many studies by different researches worldwide. Studies related to the bioenergy potential of sweet sorghum for ethanol production have been conducted in Europe (Venturi and Venturi 2003), Asia (Zhang et al. 2010), Oceania (Thomas 2009), Africa (Diaz-Chaves and Jamieson 2010), and the Americas (Kim and Day 2010, Guigou et al. 2011).

Sweet sorghum, similar to sugar cane, has succulent stems with the presence of directly fermentable sugars, which allows for harvesting and processing with the same infrastructure for ethanol production in sugar cane mills (Kim and Day 2010) and sugar cane ethanol plants. Sorghum is a short cycle crop, approximately four months, with established production systems for forage cultivars. The sorghum crop is established from seed and the production system is fully mechanized (Ratnavathi et al. 2010). For this reason, sweet sorghum may be an excellent potential to supply raw feed stock during the off season of sugar cane mills in Brazil from February to April, and thereby strengthen the national production of ethanol, reduce the idle period of these mills, and reduce fluctuations of ethanol price.

Commercial release of new sweet sorghum cultivars requires understanding the performance of potential genotypes in different environmental conditions. Genotype by environment interactions can complicate the recommendation of cultivars for different environments, making adaptability and stability analyses necessary. The study of adaptability and stability allows the identification of genotypes with predictable behavior in specific or general environments, and the identification of genotypes sensitive to positive environmental variations (Cruz et al. 2004).

There are several methods for analyzing adaptability and stability of genotypes when grown in different environments. The choice of using certain analytical method of experimental data depends mainly on the number of environments available, the accuracy required, and the type of information desired. Ideally, the assessment methodology should be reliable, easy to interpret, require few statistics, and can be used for both small and large numbers of environments (Schmildt et al. 2011).

\footnotetext{
${ }^{1}$ Universidade Federal de São João del-Rei, Departamento de Engenharia de Biossistemas, Praça Dom Helvécio 74, 36.301-160, São João del Rei, MG, Brazil. *E-mail: vanderfsouza@gmail.com

2 Embrapa Milho e Sorgo, MG 424, km 45, 35.701-970, Sete Lagoas, MG, Brazil

${ }^{3}$ Universidade Estadual de Montes Claros, Departamento de Ciências Agrárias, Campus de Janaúba, Reinaldo Viana 2630, 39.440-000, Janaúba, MG, Brazil

4 Texas A\&M University, Department of Soil and Crop Sciences, College Station, TX, 77843-2474, USA
} 
The Annicchiarico (1992) method is based on analysis of variance, and stands out because it is of easy use. This method is based on the estimation of a risk index recommendation of using certain cultivar. For that, genotypic averages are converted to a percentage base in relation to the average values of a specific environment. Thus, the mean and standard deviation are estimated for each genotype and environment in relation to the normal distribution adopted to estimate the probability of a genotype to be above average of the sites studied.

In Brazil, some authors have conducted adaptability and stability studies of forage sorghum genotypes (Oliveira et al. 2002, Silva et al. 2005). However, there is a lack of information about the adaptability and stability of sweet sorghum genotypes. Thus, the objective of this study was to evaluate phenotypic stability and adaptability for fresh biomass yield and total soluble sugar of sorghum cultivars, developed by Embrapa Maize and Sorghum.

\section{MATERIAL AND METHODS}

The experiments were conducted in the 2009/2010 season at five different locations, three in Minas Gerais

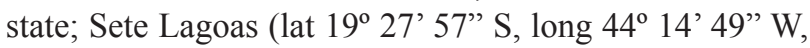
alt $767 \mathrm{~m}$ asl), Nova Porteirinha (lat $15^{\circ} 47^{\prime}$ '00” S, long $43^{\circ} 18^{\prime} 00^{\prime \prime} \mathrm{W}$, alt $533 \mathrm{~m}$ asl), and Jaíba (lat $15^{\circ} 20^{\prime} 16^{\prime \prime} \mathrm{S}$, long $43^{\circ} 40^{\prime} 26^{\prime \prime} \mathrm{W}$, alt $470 \mathrm{~m}$ asl); in Sinop - Mato Grosso (lat $11^{\circ} 50^{\prime} 53^{\prime} \mathrm{S}$, long $55^{\circ} 38^{\prime} 57^{\prime}$ ' $\mathrm{W}$, alt $384 \mathrm{~m}$ asl), and in Pelotas - Rio Grande do Sul (lat 31 ${ }^{\circ} 46^{\prime} 19^{\prime \prime}$ S, long $52^{\circ}$ 20'34" W, alt of $7 \mathrm{~m}$ asl), Brazil.

Sowing took place on October 29, in Sete Lagoas; November 17, in Jaíba; December 3, in Nova Porteirinha; December 17, in Pelotas; and February 9, in Sinop. The experiments were conducted during the rainy season in the South and Southeast regions, and the second harvest season in the Sinop, at the central-western Brazil.

Supplemental irrigation was applied at Sete Lagoas, Nova Porteirinha, and Jaíba trials during dry periods. Trials in Sinop and Pelotas were conducted under rainfed conditions. Other normally recommended cropping practices were applied during crop development in each region.

Twenty five cultivars of sweet sorghum belonging to the breeding program of Embrapa Maize and Sorghum were evaluated, 24 varieties (BR500, BR501, BR503, BR504, BR505, BRS506, BRS507, CMSXS629, CMSXS630, CMSXS631, CMSXS632, CMSXS633, CMSXS634, CMSXS635, CMSXS636, CMSXS637, CMSXS638, CMSXS639, CMSXS642, CMSXS643, CMSXS644, CMSXS646, CMSXS647 and CMSXS648), and one hybrid (BRS601).
The experimental plots consisted of four rows, $5 \mathrm{~m}$ long, spaced $0.70 \mathrm{~m}$, established in a randomized complete block design with three replications. Fertilization consisted of $400 \mathrm{~kg} \mathrm{ha}^{-1}$ of NPK (08-28-16) applied at sowing, and $200 \mathrm{~kg} \mathrm{ha}^{-1}$ of urea applied 30 days after sowing. The plant population adopted was 125,000 plants ha-1.

Evaluations were conducted in the two central rows of each plot. Determination of fresh biomass yield (FBY) was determined based on the weight of total plants in each plot, without panicles, harvested at grain physiological maturity, with the weight in $\mathrm{kg}$ per plot converted to $\mathrm{tha}^{-1}$. The content of total soluble solids (TSS) was determined using an automatic digital refractometer, measured in ${ }^{\circ}$ Brix.

Analysis of variance was first conducted for each environment. After verifying the assumptions of homogeneity of residual variances, analysis of variance for all sites and the Scott-Knott test (1974) at 5\% probability were performed. Finally, adaptability and stability analysis was conducted, after determining significant genotype by environment interaction.

The genetic model adopted for the analysis of variance was $Y_{i j k}=\mu+G_{i}+A_{j}+G A_{i j}+B / A_{j k}+e_{i j k}$, where: $Y_{i j k}$ : observation of $i^{\text {th }}$ genotype in $j^{\text {th }}$ environment, and in $k^{\text {th }}$ block; $\mu$ : general mean; $G_{i}: i^{\text {th }}$ genotype effect $(i=1,2, \ldots, 25)$; $A_{j}: j^{\text {th }}$ environment effect $(j=1,2, \ldots, 5) ; G A_{i j}$ interaction effect of the $i^{\text {th }}$ genotype in $j^{\text {th }}$ environment; $B / A_{j k}$ : effect of $k^{\text {th }}$ block in $j^{\text {th }}$ environment ( $k=1,2$ and 3$) ; e_{i j k}$ : random error. Genotype and environment effects were considered fixed.

The Annicchiarico (1992) methodology was adopted to study the adaptability and stability. This methodology allows estimating a confidence index $(\mathrm{Wi})$ for a given genotype classified above the average performance between environments. It is considered the ideal genotype that provides the lowest risk of being adopted, in other words, the genotype that presents the greatest absolute value for the confidence index.

The model for the analysis of adaptability and stability is based on the formula $W_{i}=\bar{Y}_{i .}-Z_{(1-\alpha)} \cdot S_{i}$, where: $W_{i}$ : confidence index (\%); $\bar{Y}_{i}$ : average of $t^{\text {th }}$ genotype in percentage; $Z_{(1-\alpha)}$ : cumulative normal distribution function; $S_{i}$ : standard deviation of $i^{t h}$ genotype in percentages.

High confidence index occur for genotypes that have higher averages and less deviation for traits evaluated. The value of the standardized normal distribution $Z_{(1-\alpha)}$ set was 0.2734 , for $\alpha=25 \%$, which represents $75 \%$ level of confidence that the genotypes, at minimum, had values above the environmental average. 
After analyzing the adaptability and overall stability, the confidence index was determined according to favorable or unfavorable environments, considering the means and the variances related to each type of environment. For this reason, environmental indices $(I j)$ were calculated as the difference between each environment mean and the overall mean from all environments. These indices classified the environmental conditions during the trials as favorable when positive and unfavorable when negative.

Thus, $W_{i(f)}=\bar{Y}_{i .(f)}-Z_{(1-\alpha)} \cdot S_{i(f)}$ only considers environments classified as favorable, and $W_{i(d)}=\bar{Y}_{i .(d)}-Z_{(1-\alpha)} \cdot S_{i(d)}$ only considers environments classified as unfavorable. All statistical analyses were performed using the Genes software (Cruz 2009).

\section{RESULTS AND DISCUSSION}

According to F test in the joint analyzes (Table 1), genotype by environment interaction showed significant effects $(\mathrm{P}<0.01)$ for FBY and TSS. This indicates distinct performance changes of sweet sorghum cultivars evaluated in different environments. The Scott-Knott (1974) cluster means test was used for classification of FBY (Table 2) and TSS means (Table3).
Table 1. Summary of joint analysis of variance for fresh biomass yield (FBY), and content of total soluble solids (TSS) of 25 genotypes of sweet sorghum, grown in different environments, in 2009/2010 season in Brazil

\begin{tabular}{lccc}
\hline \multirow{2}{*}{ Source of variation } & \multirow{2}{*}{ df } & \multicolumn{2}{c}{ MS } \\
\cline { 3 - 4 } & & FBY $\left(\mathrm{t} \mathrm{ha}^{-1}\right)$ & TSS $\left({ }^{\circ} \mathrm{Brix}\right)$ \\
\hline Genotypes (G) & 24 & $198.16^{* *}$ & $39.50^{* *}$ \\
Environments (E) & 4 & $7651.70^{* *}$ & $152.37^{* *}$ \\
G x E & 96 & $93.62^{* *}$ & $6.00^{* *}$ \\
Blocks/E & 10 & 155.59 & 12.95 \\
\hline Error & 240 & 41.46 & 3.21 \\
C.V.(\%) & & 14.86 & 10.38 \\
\hline
\end{tabular}

** and *: Significant at $1 \%$ and $5 \%$ probability for the $\mathrm{F}$ test, respectively.

Overall environment means for FBY ranged from 27.31 $\mathrm{t} \mathrm{ha}^{-1}$ in Pelotas - RS to $51.62 \mathrm{t} \mathrm{ha}^{-1}$ in Nova Porteirinha MG. Teixeira et al. (1999) presented similar results when evaluating the sorghum cultivar BR505, in different seasons, with values ranging from $20.85 \mathrm{t} \mathrm{ha}^{-1}$ to $52.70 \mathrm{t} \mathrm{ha}^{-1}$.

The value observed for Pelotas - RS can be considered underestimated due to the occurrence of a prolonged drought without supplemental irrigation during plant growth. In this environment, there were no significant differences between genotypes, and the coefficient of variation of $26.90 \%$ was

Table 2. Average of fresh biomass yield (FBY)*, in t ha ${ }^{-1}$, of 25 cultivars of sweet sorghum grown in five environments, in $2009 / 2010$ season in Brazil

\begin{tabular}{|c|c|c|c|c|c|c|c|c|c|c|c|c|c|c|c|c|}
\hline \multirow{3}{*}{$\begin{array}{l}\text { Genotypes } \\
\text { CMSXS629 }\end{array}$} & \multicolumn{15}{|c|}{ Environments } & \multirow{3}{*}{$\begin{array}{l}\text { Means } \\
43.41\end{array}$} \\
\hline & \multicolumn{3}{|c|}{ Sete Lagoas-MG } & \multicolumn{3}{|c|}{ Nova Porteirinha-MG } & \multicolumn{3}{|c|}{ Jaíba-MG } & \multicolumn{3}{|c|}{ Pelotas-RS } & \multicolumn{3}{|c|}{ Sinop-MT } & \\
\hline & 48.48 & $\mathrm{~b}$ & $\mathrm{~A}$ & 53.90 & $\mathrm{a}$ & $\mathrm{A}$ & 35.76 & $\mathrm{~b}$ & B & 27.57 & $\mathrm{a}$ & B & 51.33 & $\mathrm{a}$ & A & \\
\hline CMSXS630 & 57.24 & a & A & 46.52 & $\mathrm{~b}$ & A & 46.71 & a & A & 26.48 & $\mathrm{a}$ & B & 48.10 & $\mathrm{~b}$ & A & 45.01 \\
\hline CMSXS631 & 46.00 & $\mathrm{~b}$ & A & 50.14 & $\mathrm{~b}$ & A & 39.38 & $\mathrm{~b}$ & A & 32.33 & a & $\mathrm{B}$ & 45.52 & $\mathrm{~b}$ & A & 42.67 \\
\hline CMSXS632 & 46.19 & $\mathrm{~b}$ & A & 43.38 & $\mathrm{~b}$ & A & 36.81 & $\mathrm{~b}$ & $\mathrm{~B}$ & 26.14 & $\mathrm{a}$ & $\mathrm{B}$ & 45.05 & $\mathrm{~b}$ & A & 39.51 \\
\hline CMSXS633 & 49.05 & $\mathrm{~b}$ & A & 53.81 & $\mathrm{a}$ & A & 42.29 & a & $\mathrm{B}$ & 22.00 & a & $\mathrm{C}$ & 40.19 & b & B & 41.47 \\
\hline CMSXS636 & 40.48 & b & A & 45.29 & $\mathrm{~b}$ & A & 30.90 & $\mathrm{~b}$ & B & 15.90 & $\mathrm{a}$ & $\mathrm{C}$ & 44.48 & $\mathrm{~b}$ & A & 35.41 \\
\hline CMSXS637 & 53.43 & $\mathrm{a}$ & A & 48.05 & b & A & 28.90 & $\mathrm{~b}$ & B & 25.67 & $\mathrm{a}$ & B & 43.33 & b & A & 39.88 \\
\hline CMSXS638 & 50.29 & b & A & 54.19 & $\mathrm{a}$ & A & 37.90 & $\mathrm{~b}$ & B & 28.05 & $\mathrm{a}$ & B & 37.14 & b & B & 41.51 \\
\hline CMSXS639 & 47.24 & b & A & 46.90 & $\mathrm{~b}$ & A & 39.76 & $\mathrm{~b}$ & A & 23.19 & $\mathrm{a}$ & B & 47.33 & $\mathrm{~b}$ & A & 40.88 \\
\hline BRS506 & 49.05 & $\mathrm{~b}$ & A & 59.62 & $\mathrm{a}$ & A & 43.05 & $\mathrm{a}$ & B & 30.05 & $\mathrm{a}$ & $\mathrm{C}$ & 55.62 & $\mathrm{a}$ & A & 47.48 \\
\hline BR507 & 48.19 & b & A & 52.29 & b & A & 44.48 & $\mathrm{a}$ & A & 25.14 & $\mathrm{a}$ & B & 44.48 & b & A & 42.92 \\
\hline CMSXS646 & 60.19 & $\mathrm{a}$ & A & 48.67 & b & B & 44.29 & $\mathrm{a}$ & B & 26.62 & $\mathrm{a}$ & $\mathrm{C}$ & 42.86 & b & B & 44.53 \\
\hline CMSXS647 & 58.19 & a & A & 60.43 & $\mathrm{a}$ & A & 48.43 & $\mathrm{a}$ & B & 28.43 & $\mathrm{a}$ & $\mathrm{C}$ & 61.33 & $\mathrm{a}$ & A & 51.36 \\
\hline CMSXS648 & 47.43 & b & B & 61.29 & $\mathrm{a}$ & A & 40.71 & $\mathrm{a}$ & $\mathrm{C}$ & 31.43 & $\mathrm{a}$ & $\mathrm{C}$ & 52.86 & $\mathrm{a}$ & B & 46.74 \\
\hline BR500 & 44.19 & b & A & 45.86 & $\mathrm{~b}$ & A & 30.95 & $\mathrm{~b}$ & B & 26.81 & $\mathrm{a}$ & B & 52.19 & $\mathrm{a}$ & A & 40.00 \\
\hline BR501 & 48.00 & b & B & 57.14 & a & A & 54.29 & a & A & 18.33 & a & $\mathrm{C}$ & 41.81 & b & B & 43.91 \\
\hline BR503 & 52.95 & $\mathrm{a}$ & A & 49.76 & b & A & 47.52 & $\mathrm{a}$ & A & 23.91 & $\mathrm{a}$ & B & 27.05 & b & B & 40.24 \\
\hline BR505 & 56.29 & $\mathrm{a}$ & A & 46.90 & b & A & 37.48 & $\mathrm{~b}$ & B & 30.86 & a & B & 49.90 & $\mathrm{a}$ & A & 44.29 \\
\hline BR504 & 40.48 & b & A & 44.38 & b & A & 37.33 & $\mathrm{~b}$ & A & 26.62 & $\mathrm{a}$ & B & 46.86 & b & A & 39.13 \\
\hline BRS601 & 49.71 & b & A & 60.19 & $\mathrm{a}$ & A & 45.33 & $\mathrm{a}$ & B & 32.29 & a & $\mathrm{C}$ & 43.33 & b & $\mathrm{B}$ & 46.17 \\
\hline Means & 50.97 & & & 51.62 & & & 39.86 & & & 27.31 & & & 46.86 & & & 43.32 \\
\hline
\end{tabular}

* means followed by the same lowercase and same capital letters do not differ at same column and row, respectively, by Scott Knott test at 5\% probability. 
Table 3. Averages of total soluble solids (TSS)* in ${ }^{\circ}$ Brix of 25 cultivars of sweet sorghum grown in five environments, in 2009/2010 season in Brazil

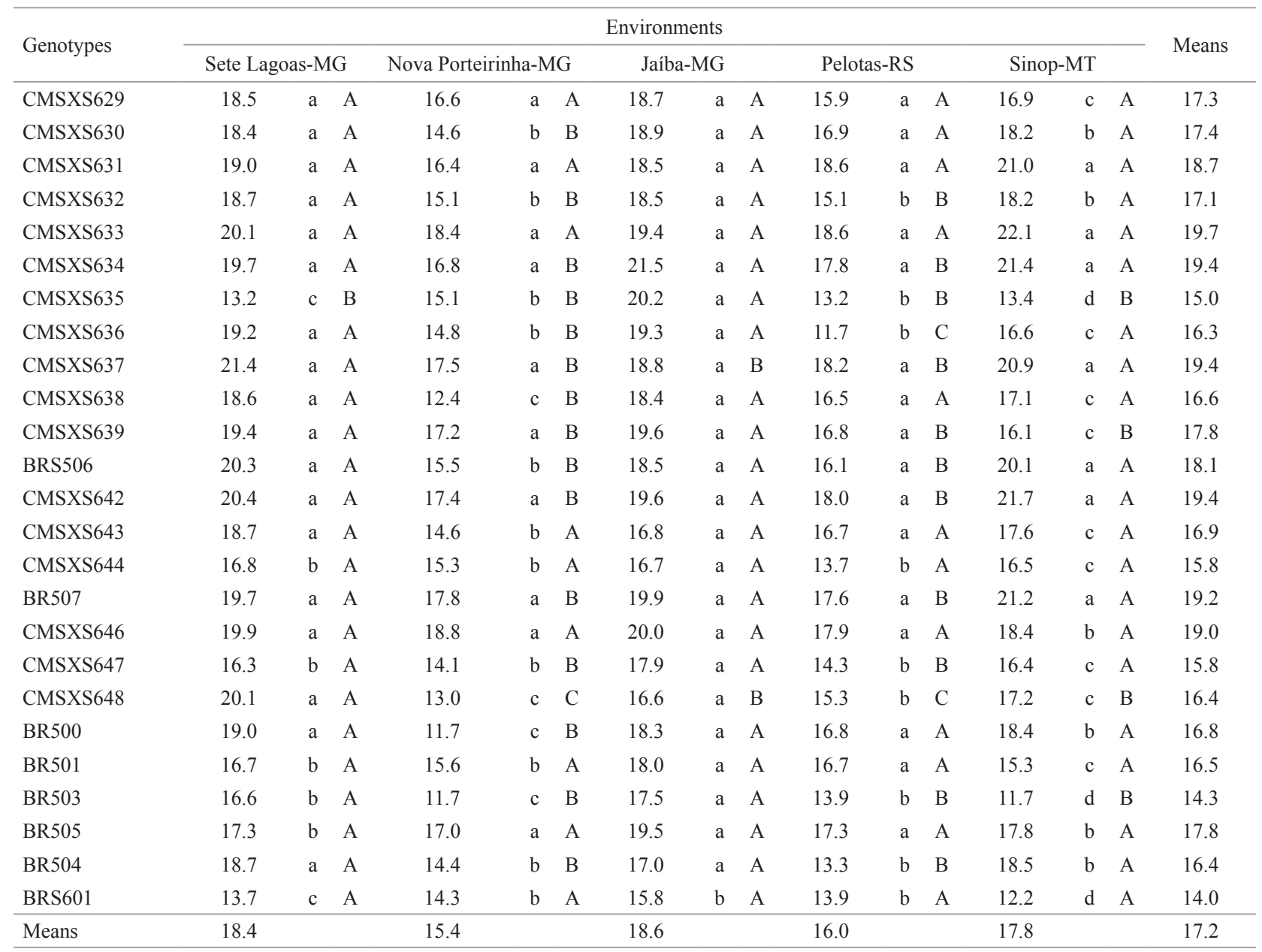

* means followed by the same lower case and same capital letters do not differ at the same column and row, respectively, by Scott Knott test at $5 \%$ probability.

higher compared with all other environments, that showed values ranging from $9.36 \%$ to $16.59 \%$.

Similarly, the genotypes showed significant differences in all environments for TSS, with the overall mean ranging between $15.4^{\circ}$ Brix in Nova Porteirinha - MG and $18.6^{\circ}$ Brix in Jaíba - MG. The average values for FBY and TSS of this study confirmed data presented by Channappagoudar et al. (2007). Since these characters are positively correlated with ethanol production (Guigou et al. 2011), cultivars with the highest values for both characters are the most suitable for agronomic processing.

Thirteen genotypes (CMSXS629, CMSXS630, CMSXS634, CMSXS635, BRS506, CMSXS643, CMSXS644, CMSXS646, CMSXS647, CMSXS648, BR501, BR505 and BRS601) had FBY higher than the overall mean (43.32 $\mathrm{t} \mathrm{ha}^{-1}$ ) across environments, and CMSXS629, CMSXS630, CMSXS634, BRS506, CMSXS646, and BR505 were also present in the group that showed superior performance for TSS compared to overall environment mean of $17.2^{\circ}$ Brix. Although the other genotypes showed significant FBY, they had low measurement for TSS, or vice-versa.

According to the environments classification, Sete Lagoas - MG, and Sinop - MT were considered favorable environments for both FBY and TSS. Nova Porteirinha MG was classified as favorable for FBY and unfavorable for TSS, and Jaíba - MG was classified as unfavorable for FBY and favorable for TSS. Lastly, Pelotas - RS was classified as unfavorable for both traits (Table 4).

From the adaptability and overall stability assessment, we observed that the genotypes CMSXS647, CMSXS644, CMSXS634, BRS506, CMSXS648, CMSXS630, CMSXS646, CMSXS635 and BRS601 had the lowest risk of having behavior below average for FBY, considering $75 \%$ confidence (Table 5). For TSS, genotypes CMSXS633, 
Table 4. Environmental indices ( $I J)$ and classification of favorable or unfavorable environments for cultivation, according to the methodology of Annicchiarico (1992). Values obtained by evaluating the characters of fresh biomass yield (FBY) and content of total soluble solids (TSS) of 25 genotypes of sorghum, grown in five environments, in the season 2009/2010 in Brazil

\begin{tabular}{lcccc}
\hline \multirow{2}{*}{ Environment } & \multicolumn{2}{c}{ FBY } & & TSS \\
\cline { 2 - 5 } & Index & Class & Index & Class \\
\hline Sete Lagoas - MG & 5.69 & Favorable & 1.16 & Favorable \\
Nova Porteirinha - MG & 6.34 & Favorable & -1.80 & Unfavorable \\
Jaíba - MG & -5.42 & Unfavorable & 1.31 & Favorable \\
Pelotas - RS & -17.97 & Unfavorable & -1.22 & Unfavorable \\
Sinop - MT & 1.58 & Favorable & 0.55 & Favorable \\
\hline
\end{tabular}

Table 5. Parameters of adaptability and overall stability $(W i)$ in favorable environments $\left(W i_{(f)}\right)$ and in unfavorable environments $\left(W i_{(d)}\right)$ of 25 genotypes of sweet sorghum for fresh biomass yield (FBY), in $\mathrm{t} \mathrm{ha}^{-1}$, based on the methodology of Annicchiarico (1992), according to results obtained in five different environments in 2009/2010 season in Brazil

\begin{tabular}{|c|c|c|c|c|c|}
\hline \multicolumn{2}{|c|}{ General } & \multicolumn{2}{|c|}{ Favorable environments } & \multicolumn{2}{|c|}{ Unfavorable environments } \\
\hline Genotype & Wi & Genotype & $\mathrm{Wi}_{(\mathrm{f})}$ & Genotype & $\mathrm{Wi}_{(\mathrm{d})}$ \\
\hline CMSXS647 & 114.85 & CMSXS647 & 118.26 & BRS601 & 115.10 \\
\hline CMSXS634 & 107.32 & CMSXS644 & 109.76 & CMSXS647 & 109.42 \\
\hline BRS506 & 105.47 & CMSXS643 & 106.81 & BRS506 & 108.61 \\
\hline CMSXS630 & 104.47 & CMSXS648 & 101.02 & CMSXS631 & 104.80 \\
\hline CMSXS646 & 100.82 & BRS506 & 100.67 & CMSXS630 & 103.14 \\
\hline BRS601 & 100.24 & CMSXS635 & 99.77 & CMSXS646 & 101.64 \\
\hline CMSXS635 & 99.32 & CMSXS629 & 98.72 & BR505 & 99.83 \\
\hline CMSXS643 & 98.18 & CMSXS646 & 98.65 & CMSXS634 & 98.52 \\
\hline BR505 & 94.83 & CMSXS642 & 94.95 & BR503 & 97.24 \\
\hline CMSXS638 & 93.35 & CMSXS633 & 94.89 & BR504 & 94.82 \\
\hline CMSXS639 & 92.44 & CMSXS631 & 94.14 & CMSXS632 & 93.38 \\
\hline CMSXS633 & 92.02 & BRS601 & 93.75 & CMSXS629 & 93.16 \\
\hline CMSXS642 & 91.86 & CMSXS638 & 93.37 & CMSXS639 & 89.46 \\
\hline CMSXS632 & 91.51 & BR505 & 92.88 & CMSXS633 & 88.38 \\
\hline BR501 & 90.43 & BR501 & 91.90 & BR501 & 88.30 \\
\hline CMSXS637 & 89.04 & BR 500 & 90.63 & CMSXS642 & 87.13 \\
\hline BR 500 & 88.98 & CMSXS632 & 88.61 & CMSXS643 & 85.65 \\
\hline
\end{tabular}

CMSXS642, CMSXS634, CMSXS637, BR507, CMSXS646, CMSXS631, BRS506, BR505 and CMSXS639 had the lowest risk (Table 6). However, only genotypes CMSXS634, BRS506, and CMSXS646 showed high risk indices $\left(W_{\mathrm{i}}>\right.$ 100) considering FBY and TSS simultaneously, qualifying them as the most stable and suitable for ethanol production in all environments (Figure 1).
Some genotypes, such as CMSXS647 in favorable environments, and BRS601 in unfavorable environments, presented high $W_{\mathrm{i}}$ for FBY, with performances $18.26 \%$ and $15.10 \%$ higher than average. But for TSS, they were $8.58 \%$ and $11.54 \%$ lower than average, respectively. The reverse also occurred to CMSXS642 in favorable environments, and CMSXS633 in unfavorable environments, which 
Table 6. Parameters of adaptability and overall stability $(W i)$ in favorable environments $\left(W i_{(f)}\right)$ and in unfavorable environments $\left(W i_{(d)}\right)$ of 25 genotypes of sorghum, for total soluble solids (TSS) or ${ }^{\circ}$ Brix in the juice, based in the methodology of Annicchiarico (1992), according to results obtained in five different environments in the 2009/2010 season in Brazil

\begin{tabular}{|c|c|c|c|c|c|}
\hline \multicolumn{2}{|c|}{ General } & \multicolumn{2}{|c|}{ Favorable environments } & \multicolumn{2}{|c|}{ Unfavorable environments } \\
\hline CMSXS633 & 112.44 & CMSXS634 & 112.48 & CMSXS633 & 117.07 \\
\hline CMSXS634 & 111.04 & CMSXS633 & 109.71 & CMSXS637 & 113.61 \\
\hline CMSXS637 & 110.75 & CMSXS637 & 109.29 & CMSXS642 & 112.42 \\
\hline CMSXS646 & 108.76 & CMSXS646 & 105.88 & CMSXS634 & 109.42 \\
\hline CMSXS631 & 106.43 & BRS506 & 105.70 & CMSXS631 & 109.29 \\
\hline BRS506 & 102.95 & CMSXS631 & 104.26 & BR505 & 108.54 \\
\hline BR505 & 101.66 & CMSXS630 & 101.09 & CMSXS639 & 106.76 \\
\hline CMSXS632 & 98.20 & BR505 & 98.23 & CMSXS630 & 98.04 \\
\hline CMSXS643 & 96.44 & CMSXS638 & 98.17 & CMSXS643 & 97.44 \\
\hline BR 500 & 93.83 & CMSXS639 & 98.16 & CMSXS632 & 95.38 \\
\hline BR501 & 93.69 & CMSXS629 & 97.71 & CMSXS647 & 89.79 \\
\hline CMSXS638 & 93.52 & BR504 & 97.15 & CMSXS644 & 89.65 \\
\hline CMSXS648 & 92.40 & CMSXS648 & 95.77 & BRS601 & 88.46 \\
\hline BR504 & 92.39 & CMSXS643 & 95.45 & CMSXS648 & 87.49 \\
\hline CMSXS647 & 90.74 & CMSXS647 & 91.42 & CMSXS638 & 87.33 \\
\hline
\end{tabular}

presented performance $10.51 \%$ and $17.07 \%$ higher than average for TSS and presented performance $5.05 \%$ and $11.62 \%$ below the average for FBY, respectively.

The genotypes that have excelled in favorable environmental conditions (Sete Lagoas - MG and Sinop - MT) for both characters were CMSXS634, CMSXS630, and BRS506, since they showed confidence indices above the environmental average for both FBY and TSS. In percentage, these genotypes exceeded the environmental average by $10.81 \%, 4.51 \%$ and $0.67 \%$ for FBY and by $12.48 \%$, $1.09 \%$ and $5.70 \%$ for TSS, respectively. Likewise, genotypes CMSXS631, BRS506, and CMSXS646 stood out in unfavorable environment (Pelotas - RS), for presenting concurrently, confidence indices above average for both FBY $(4.8 \%, 8.61 \%$ and $1.64 \%)$ and for TSS $(9.29 \%, 0.25 \%$ and $14.71 \%)$.
The Annicchiarico method allowed easy interpretation, based on analysis of only one parameter, and also allowed the ranking of genotypes more adapted and stable. Silva et al. (2005), using another method of stability and adaptability to evaluate fresh and dry biomass yield in forage sorghum cultivars, identified BRS506, among the materials evaluated, as the most suitable to favorable and unfavorable environments, in addition to presenting the highest yield for fresh biomass $\left(49.33 \mathrm{t} \mathrm{ha}^{-1}\right)$. In the present study, the cultivar BRS506 also showed general and specific adaptability and stability for favorable and unfavorable environments for both FBY and TSS. However, the genotype CMSXS634 showed superior performance in general adaptation and in particular favorable environments, moreover, genotype CMSXS646 presented general and specific adaptation to unfavorable environments for both traits. 


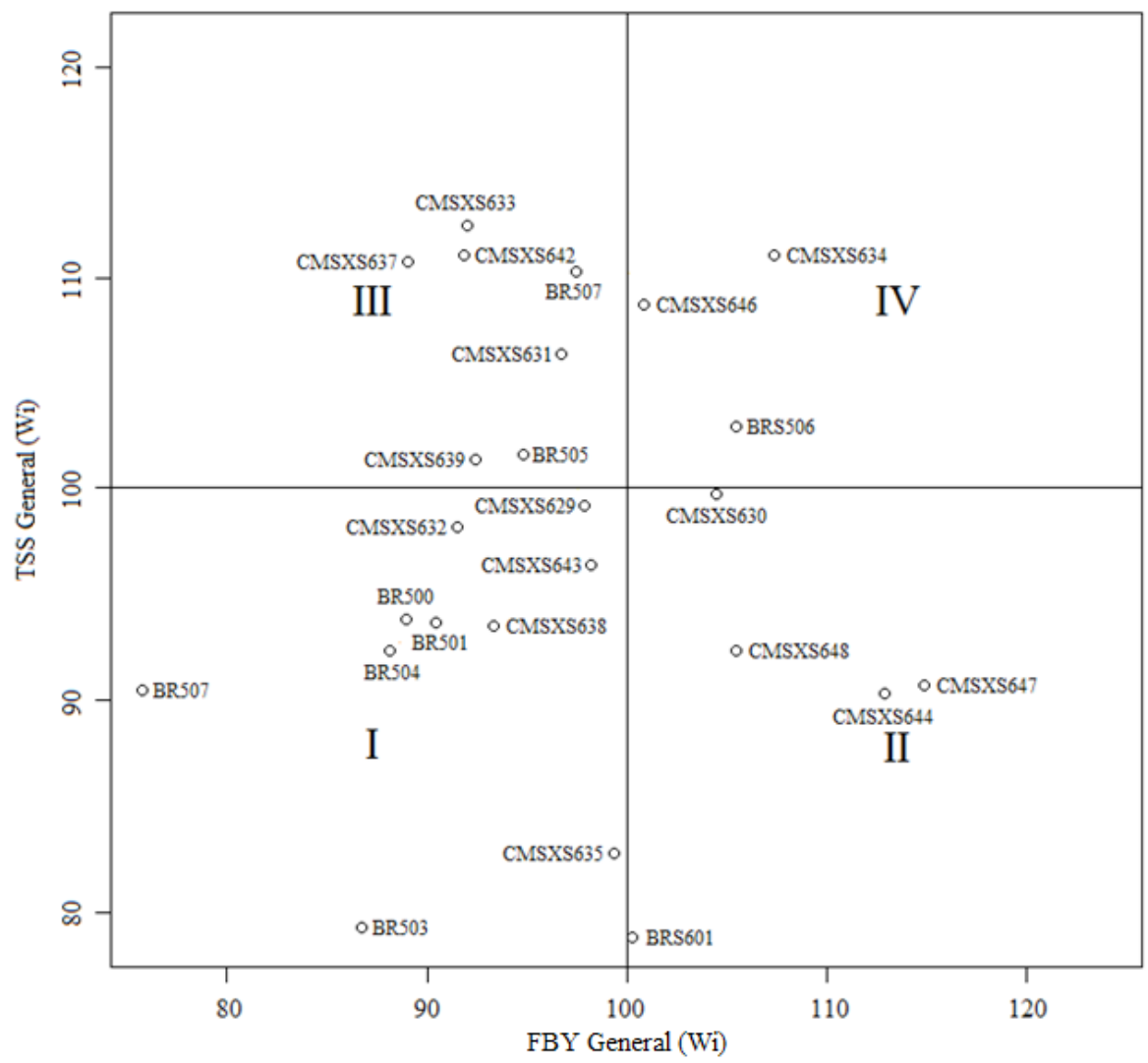

Figure 1. Display of the overall standings of the 25 sweet sorghum cultivars grown in five different environments in 2009/2010 season in Brazil, evaluated for fresh biomass yield (FBY) and total soluble solids (TSS), according to the method of Annicchiarico (1992). Quadrant I: Genotypes without adaptability and overall stability for FBY and TSS. Quadrant II: Genotypes with adaptability and overall stability for FBY. Quadrant III: Genotypes with adaptability and overall stability for TSS. Quadrant IV: Genotypes with adaptability and overall stability for FBY and TSS.

These results indicate that improvements have been made in the sweet sorghum breeding program of Embrapa Maize and Sorghum, since higher yielding cultivars, adapted and stable for both general and specific environments were observed, being possible candidates for commercial release. Moreover, they can assist in the decision of farmers in adopting new cultivars. However, new studies of the adaptability and stability in different seasons and in new environments are important to obtain more complete information on the performance of genotypes in specific regions.

\section{ACKNOWLEDGEMENTS}

Embrapa Maize and Sorghum, the European Commission FP7 project "SweetFuel" and Fapemig for financial support. Unimontes and Capes for the scholarship.

\section{Adaptabilidade e estabilidade de cultivares de sorgo sacarino}

Resumo - O objetivo do presente estudo foi avaliar a adaptabilidade e estabilidade fenotípica de 25 cultivares de sorgo sacarino da Embrapa Milho e Sorgo. Os experimentos foram conduzidos em cinco ambientes, três no Estado de Minas Gerais e os demais nas cidades de Sinop - MT e Pelotas - RS, no delineamento em blocos ao acaso, com três repetições. Foram avaliados a produção de biomassa fresca (PBF) e o teor de sólidos solúveis totais (SST) do caldo. Na análise de variância conjunta, a interação genótipos com ambientes foi significativa para os dois caracteres avaliados. Para análise da adaptabilidade e estabilidade, utilizou-se o método de Annicchiarico. Os genótipos CMSXS634, BRS506 e CMSXS646 foram os mais adaptados e estáveis para PBF e SST concomitantemente, sendo CMSXS634 mais adaptado a ambientes favoráveis e CMSXS646 a ambientes desfavoráveis.

Palavras-chave: Sorghum bicolor, interação genótipos x ambientes, Annicchiarico, biocombustivel, etanol. 


\section{REFERENCES}

Annicchiarico P (1992) Cultivar adaptation and recommendation from alfalfa trials in Northern Italy. Journal of Genetics and Plant Breeding 46: 269-278.

Channappagoudar BB, Biradar NR, Patil JB and Hiemath SM (2007) Assessment of sweet sorghum gentypes for cane yield, juice characters and sugar levels. Karmataka Journal of Agricultural Sciences 20: $294-296$.

Cruz CD (2009) Programa Genes - aplicativo computacional em genética e estatística. Version 2009.7.0. Available at $<$ http://www. ufv.br/dbg/genes/Genes Br.htm> Accessed on 15 Feb., 2010.

Cruz CD, Regazzi AJ and Carneiro PCS (2004) Modelos biométricos aplicados ao melhoramento genético. Editora UFV, Viçosa, 480p.

Diaz-Chaves R and Jamieson C (2010) Biofuels possibilities in the Southern Africa context. Journal of Biobased Materials and Bioenergy 4: 256-266.

Guigou M, Lareo C, Pérez LV, Lluberas ME, Vázquez D and Ferrari MD (2011) Bioethanol production from sweet sorghum: Evaluation of post-harvest treatments on sugar extraction and fermentation. Biomass and Bioenergy 35: 3058-3062.

Kim M and Day DF (2010) Composition of sugar cane, energy cane, and sweet sorghum suitable for ethanol production at Louisiana sugar Mills. Journal of Industrial Microbiology and Biotechnology 38: 803-807.

Oliveira JS, Ferreira RP, Cruz CD, Pereira AV, Botrel MA, Pinho RG, Rodrigues JAS, Lopes FCF and Miranda JEC (2002) Adaptabilidade e estabilidade em cultivares de sorgo. Revista Brasileira de Zootecnia 31: $883-889$.
Ratnavathi CV, Suresh K, Vijaykumar BS, Pallavi M, Komala VV and Seetharama N (2010) Study on genotypic variation for ethanol production from sweet sorghum juice. Biomass Bioenergy 34: 947-952.

Schmildt ER, Nascimento AL, Cruz CD and Oliveira JAR (2011) Avaliação de metodologias de adaptabilidade e estabilidade de cultivares milho. Acta Scientiarum Agronomy 33: 51-58.

Scott AJ and Knott MA (1974) A cluster analysis method for grouping means in the analysis of variance. Biometrics 30: 507-512.

Silva AG, Rocha VS, Cruz CD, Sediyama T and Pinto GHF (2005) Adaptabilidade e estabilidade de cultivares de sorgo forrageiro semeados em diferentes épocas do ano. Revista Brasileira de Milho e Sorgo 4: 112-125.

Teixeira CG, Jardine JG, Nicolella G and Zaroni MH (1999) Influência da época de corte sobre o teor de açúcares de colmos de sorgo sacarino. Pesquisa Agropecuária Brasileira 34: 1601-1606.

Thomas G (2009) Integrated processing for profit. International Sugar Journal 111: 670-675.

Venturi P and Venturi G (2003) Analysis of energy comparison for crops in European agricultural systems. Biomass \& Bioenergy 25: $235-255$.

Zhang C, Xie G, Li S, Ge L and He T (2010) The productive potentials of sweet sorghum ethanol in China. Applied Energy 87: $2360-2368$ 